TITLE:

\title{
Physical and Electrochemical Properties of a Room Temperature Molten Salt: 1-ethyl-2,3- dimethylimidazolium Fluorohydrogenate
}

\author{
$\operatorname{AUTHOR}(\mathrm{S})$ :
}

MATSUMOTO, Kazuhiko; HAGIWARA, Rika

\section{CITATION:}

MATSUMOTO, Kazuhiko ...[et al]. Physical and Electrochemical Properties of a Room Temperature Molten Salt: 1-ethyl-2,3-dimethylimidazolium Fluorohydrogenate.

Electrochemistry 2005, 73(8): 730-732

ISSUE DATE:

2005-08-05

URL:

http://hdl.handle.net/2433/251204

\section{RIGHT:}

この論文は出版社版でありません。引用の際には出版社版をご確認ご 利用ください。; This is not the published version. Please cite only the published version. 


\section{Physical and electrochemical properties of a room temperature molten salt: 1-ethyl-2,3-dimethylimidazolium fluorohydrogenate}

\section{Kazuhiko MATSUMOTO and Rika HAGIWARA}

Graduate School of Energy Science, Kyoto University (Yoshida, Sakyo-ku, Kyoto 606-8501, Japan)

Received Month XX, 200X ; Accepted Month XX, 200X

A new room temperature molten salt (room temperature ionic liquid), 1-ethyl-2,3dimethylimidazolium fluorohydrogenate $\left(\operatorname{EDMIm}(\mathrm{HF})_{2.3} \mathrm{~F}\right)$, has been prepared by the reaction of $\mathrm{EDMImCl}$ and large excess of anhydrous hydrogen fluoride (aHF). EDMIm(HF) ${ }_{2.3} \mathrm{~F}$ is composed of EDMIm cation and (HF) ${ }_{n} \mathrm{~F}$ anions (fluorohydrogenate anions) and exhibits the conductivity of $56.9 \mathrm{mS} \mathrm{cm}{ }^{-1}$ and viscosity of $6.8 \mathrm{cP}$ at $298 \mathrm{~K}$. Electrochemical window of EDMIm(HF $)_{2.3} \mathrm{~F}$ determined by cyclic voltammetry using a glassy carbon electrode as a working electrode is about $2.9 \mathrm{~V}$ that is close to the window of 1-ethyl-3-methylimidazolium fluorohydrogenate $\left(\mathrm{EMIm}(\mathrm{HF})_{2.3} \mathrm{~F}\right)$ reported previously.

Key Words : Room temperature molten salt, Ionic liquid, 2-Methylimidazolium, Electrochemical stability 


\section{Introduction}

Room temperature molten salts (often called room temperature ionic liquid) have some unique properties such as nonvolatility, nonflammability and wide liquid-state temperature range. Applications of room temperature molten salts to electrochemical devices have been studied by many groups, as well as reaction media and catalysts in organic syntheses. $^{1-3)}$ Application of room temperature molten salts as electrolytes includes electrical double layer capacitor, ${ }^{4,5)}$ fuel cell, ${ }^{6-8)}$ lithium battery $^{9-12)}$ and solar cell. ${ }^{13-15)}$ Properties such as high conductivity and wide electrochemical window are preferable for these applications.

Room temperature molten salts containing fluoroanions are now widely studied because of their high stabilities in air. ${ }^{1-3)}$ The first vacuum-stable room temperature molten fluorohydrogenate, 1-ethyl-3-methylimidazolium fluorohydrogenate $\left(\mathrm{EMIm}(\mathrm{HF})_{2.3} \mathrm{~F}\right)$, was reported in 1999 (Fig. 1). ${ }^{16)}$ After the report, a series of fluorohydrogenate salts using alkylimidazolium, alkylpyridinium, alkylpyrrolidinium and alkylpiperidinium cations were prepared and characterized. ${ }^{17-20)}$ Their applications to electrochemical devices were examined as well as to organic syntheses. ${ }^{4,8,21-24)}$ They exhibit the same vacuum-stable $\mathrm{HF}$ composition, (cation $)^{+}(\mathrm{HF})_{2.3} \mathrm{~F}^{-}$, anionic species identified being $(\mathrm{HF})_{2} \mathrm{~F}^{-}$and $(\mathrm{HF})_{3} \mathrm{~F}^{-19}{ }^{19}$ 22) These two fluorohydrogenate anions exchange HF with each other. The prominent property of the series of fluorohydrogenate salts is their high conductivities induced by their low viscosities. Results of Walden's plots and pulsed-gradient spin-echo (PGSE) NMR suggested that no special conduction mechanism such as ion hopping exist in the systems. ${ }^{18,20)}$

Electrochemical stability is one of the most important factors of electrolytes for electrochemical devices. There are some reports that alkylation of the 2-position of 1,3- 
dialkylimidazolium cation increases the electrochemical stability of the imidazolium cation. $^{15)}$ In the present study, physical and electrochemical properties of the fluorohydrogenate salt of 1-ethyl-2,3-dimethylimidazolium cation $\left(\mathrm{EDMIm}^{+}\right)$shown in Fig. 1 was investigated and compared with those of the other fluorohydrogenates reported previously.

\section{Experimental}

EDMImCl was prepared by the reaction of ethyl chloride (Wako Pure Chemical Industries, purity > $99 \%$ ) and the mixture of 1,2-dimethylimidazole (Aldrich, purity $98 \%$ ) and acetonitrile dehydrated (Wako Pure Chemical Industries, purity > $99 \%$ ) at $373 \mathrm{~K}$ for one night in a sealed screw top pressure tube (Ace Glass). The obtained $\mathrm{DMImCl}$ was recrystallized several times from acetonitrile solution using ethyl acetate dehydrated (Wako Pure Chemical Industries, purity > $99 \%$ ) and dried at $373 \mathrm{~K}$ for one week under reduced pressure $(\sim 1 \mathrm{~Pa})$. $\mathrm{DMIm}(\mathrm{HF})_{n} \mathrm{~F}$ was prepared by the reaction of DMImCl and anhydrous hydrogen fluoride (aHF, Daikin Industries, purity > $99 \%$ ) dried over $\mathrm{K}_{2} \mathrm{NiF}_{6}$ (Ozark Mahoning) in a reaction tube made of tetrafluoroethyleneperfluoroalkylvinylether copolymer (PFA). Elimination of the volatile gases and addition of fresh HF were repeated several times for complete elimination of chloride in the form of hydrogen chloride. Finally, volatile gases were eliminated by pumping $(\sim 1$ $\mathrm{Pa})$.

Electrochemical and physical properties were measured in the same manner as reported previously. ${ }^{19,25)}$ 


\section{Results and Discussion}

According to the elemental analysis, the fluorohydrogenate salt obtained by the reaction of EDMImCl and $\mathrm{aHF}$ exhibits the vacuum-stable composition of $\operatorname{EDMIm}(\mathrm{HF})_{2.3} \mathrm{~F}$ at room temperature which is the same as that obtained for the other room temperature molten fluorohydrogenates. ${ }^{16-19)}$ Comparison of the IR spectrum of $\operatorname{EDMIm}(\mathrm{HF})_{2.3} \mathrm{~F}$ with those obtained for the other fluorodhydrogenates $\left(\mathrm{M}^{+}(\mathrm{HF})_{n} \mathrm{~F}^{-}, \mathrm{M}\right.$ $=$ alkali metal and alkylammonium) indicates that $\operatorname{EDMIm}(\mathrm{HF})_{2.3} \mathrm{~F}$ is composed of EDMIm $^{+},(\mathrm{HF})_{2} \mathrm{~F}^{-}$and $\left.(\mathrm{HF})_{3} \mathrm{~F}^{-} .{ }^{18}, 19,21\right)$ Table 1 shows physical properties of $\operatorname{EDMIm}(\mathrm{HF})_{2.3} \mathrm{~F}$ compared with that of $\operatorname{EMIm}(\mathrm{HF})_{2.3} \mathrm{~F} .{ }^{18)}$ Figure 2 shows the DSC thermogram of EDMIm $(\mathrm{HF})_{2.3} \mathrm{~F}$. EDMIm $(\mathrm{HF})_{2.3} \mathrm{~F}$ freezes at about $200 \mathrm{~K}$ in the cooling process. In the heating process, two melting points at 215 and $237 \mathrm{~K}$ were observed, presumably corresponding to the crystallization of $\operatorname{EDMIm}(\mathrm{HF})_{2} \mathrm{~F}$ and to $\operatorname{EDMIm}(\mathrm{HF})_{3} \mathrm{~F}$, respectively.

Figure 3 shows Arrhenius plots of the conductivity and viscosity of $\operatorname{EDMIm}(\mathrm{HF})_{2.3} \mathrm{~F}$. The conductivity and viscosity of $\operatorname{EDMIm}(\mathrm{HF})_{2.3} \mathrm{~F}$ exhibit almost linear response in the measured temperature range. The conductivity of $\mathrm{EDMIm}(\mathrm{HF})_{2.3} \mathrm{~F}$ at $298 \mathrm{~K}$ is $56.9 \mathrm{mS}$ $\mathrm{cm}^{-1}$. This value is much higher than those of the other room temperature molten salts such as $13.6 \mathrm{mS} \mathrm{cm}{ }^{-1}$ of $\mathrm{EMImBF}_{4}$ and $8.8 \mathrm{mS} \mathrm{cm}^{-1}$ of $\operatorname{EMImN}\left(\mathrm{SO}_{2} \mathrm{CF}_{3}\right)_{2} .{ }^{15}$, 26) The viscosity of $\mathrm{EDMIm}(\mathrm{HF})_{2.3} \mathrm{~F}$ at $298 \mathrm{~K}$ is $6.8 \mathrm{cP}$ which is also much lower than those of the other room temperature molten salts such as $31.8 \mathrm{cP}$ of $\mathrm{EMImBF}_{4}$ and $34 \mathrm{cP}$ of EMImN $\left(\mathrm{SO}_{2} \mathrm{CF}_{3}\right)_{2}$. As described in the previous studies, the low viscosity is one of the prominent characteristics of fluorohydrogenate salts which provides high conductivities to them. ${ }^{18,20)}$ 
Figure 4 shows cyclic voltammograms of glassy carbon electrodes in $\operatorname{EDMIm}(\mathrm{HF})_{2.3} \mathrm{~F}$ and $\operatorname{EMIm}(\mathrm{HF})_{2.3} \mathrm{~F}$. As mentioned in the introduction part, according to some reports, the alkylation of the 2-position of imidazolium cation improves the electrochemical stability of the salt. The electrochemical window of $\operatorname{EDMIm}(\mathrm{HF})_{2.3} \mathrm{~F}$ is $2.9 \mathrm{~V}$ which is close to that of $\operatorname{EMIm}(\mathrm{HF})_{2.3} \mathrm{~F}(3 \mathrm{~V})$. It is known that cathode limits of fluorohydrogenate salts involve hydrogen gas evolution from $(\mathrm{HF})_{n} \mathrm{~F}^{-}$. In the case of the tetraalkylammonium fluorohydrogenates $\left(\mathrm{R}_{4} \mathrm{~N}(\mathrm{HF})_{n} \mathrm{~F}\right)$ of which the $n$ is more than 3.0, hydrogen gas easily evolves at the cathode limit, whereas in the case less than 3.0, the reduction of cation is involved. ${ }^{27)}$ On the other hand, cathode-limit potential of $\operatorname{EMIm}(\mathrm{HF})_{n} \mathrm{~F}$ is not sensitive to $n$ in the region of $1<n<2.3{ }^{28)}$ The cathode limit of $\operatorname{EDMIm}(\mathrm{HF})_{2.3} \mathrm{~F}$ is about $-1.8 \mathrm{~V} v s . \mathrm{Fc}^{+} / \mathrm{Fc}$ and close to that of $\mathrm{EMIm}(\mathrm{HF})_{2.3} \mathrm{~F}$. Taking account that EMIm cation is reduced at about $-2.5 \mathrm{~V}$ vs. $\mathrm{Fc}^{+} / \mathrm{Fc}^{10)}$, hydrogen gas evolution is predominant in the cathode limits of $\operatorname{EDMIm}(\mathrm{HF})_{2.3} \mathrm{~F}$ and $\mathrm{EMIm}(\mathrm{HF})_{2.3} \mathrm{~F}$. Aromatic compounds such as benzene are electrochemically fluorinated in fluorohydrogenate salts. ${ }^{24,27)}$ The more negative anode limit of $\operatorname{EMIm}(\mathrm{HF})_{2.3} \mathrm{~F}$ than those of the other EMIm salts such as $\mathrm{EMImBF}_{4}$ or $\mathrm{EMImN}\left(\mathrm{SO}_{2} \mathrm{CF}_{3}\right)_{2}$ is probably due to the oxidation accompanied by fluorination of EMIm cation under the existence of fluorohydrogenate anion. Potential of the anode limit of $\operatorname{EDMIm}(\mathrm{HF})_{2.3} \mathrm{~F}$ is close to that of $\operatorname{EMIm}(\mathrm{HF})_{2.3} \mathrm{~F}$, but the current density of the peak at around $1.1 \mathrm{~V}$ in the cyclic voltammogram of $\operatorname{EDMIm}(\mathrm{HF})_{2.3} \mathrm{~F}$ is smaller than that of $\operatorname{EMIm}(\mathrm{HF})_{2.3} \mathrm{~F}$. This observation indicates that the methylation of the 2-position of imidazolium cation suppresses the electrochemical fluorination of the cation. 


\section{Acknowledgement}

This work was supported by Grant in Aid for Scientific Research (No. 13555237) by Japan Society for the Promotion of Science and The 21st Century COE Program "Establishment of COE on Sustainable-Energy System" from Japanese Ministry of Education, Culture, Sports, Science and Technology. One of the authors, K. Matsumoto, thanks to Japan Society of the Promotion of Science for the financial support to the research fellow. 


\section{References}

(1) T. Welton, Chem. Rev., 99, 2071 (1999).

(2) P. Wasserscheid and W. Kein, Angew. Chem. Int. Ed., 39, 3772 (2000).

(3) R. Hagiwara, Electrochemistry, 70, 130 (2002).

(4) M. Ue, M. Takeda, A. Toriumi, A. Kominato, R. Hagiwara, Y. Ito, J. Electrochem. Soc., 150, A499 (2003).

(5) M. Ue, M. Takeda, T. Takahashi, M. Takehara, Electrochem. Solid-State Lett., 5, A119 (2002).

(6) M.A.B.H. Susan, A. Noda, S. Mitsushima, M. Watanabe, Chem. Commun., 2003, 938.

(7) A. Noda, M. A. B. H. Susan, K. Kudo, S. Mitsushima, K. Hayamizu, M. Watanabe, J. Phys. Chem. B, 107, 4024 (2003).

(8) Y. Tamba, K. Matsumoto, T. Nohira, R. Hagiwara, Y. Ito, Abstracts of the 71st Meeting of the Electrochemical Society of Japan, p. 393.

(9) H. Nakagawa, S, Izuchi, K. Kuwana, T. Nukuda, Y. Aihara, J. Electrochem. Soc., 150, A695 (2003).

(10) H. Sakaebe, H. Matsumoto, Electrochem. Commun., 5, 594 (2003).

(11) T. Fujinami, Y. Buzoujima, J. Power Sources, 119-121, 438 (2003).

(12) N. Koura, K. Etoh, Y. Idemoto, F. Matsumoto, Chem. Lett., 2001, 1320.

(13) N. Papageorgiou, Y. Athanassov, M. Armand, P. Bonhôte, H. Pettersson A. Azam, M. Grätzel, J. Electrochem. Soc., 143, 3099 (1996).

(14) H. Matsumoto, T. Matsuda, T. Tsuda, R. Hagiwara, Y. Ito, Y. Miyazaki, Chem. Lett., 2001, 26. 
(15) P. Bonhôte, A. -P. Dias, M. Armand, N. Papageorgiou, K. Kalyanasundaram and M. Grätzel, Inorg. Chem., 35, 1168 (1996).

(16) R. Hagiwara, T. Hirashige, T. Tsuda, Y. Ito, J. Fluorine Chem., 99, 1 (1999).

(17) R. Hagiwara, T. Hirashige, T. Tsuda, Y. Ito, J. Electrochem. Soc., 149, D1 (2002).

(18) R. Hagiwara, K. Matsumoto, Y. Nakamori, T. Tsuda and Y. Ito, H. Matsumoto, K. Momota, J. Electrochem. Soc., 150, D195 (2003).

(19) K. Matsumoto R. Hagiwara, Y. Ito, Electrochem. Solid-State Lett., 7, E 41 (2004).

(20) Y. Saito, K. Hirai, K. Matsumoto, R. Hagiwara, Y. Miyazaki, J. Phys. Chem. B, in press.

(21) K. Matsumoto, R. Hagiwara, Y. Ito, J. Fluorine Chem., 115 (2002) 133.

(22) K. Matsumoto, R. Hagiwara, R. Yoshida, Y. Ito, Z. Mazej, P. Benkič, B. Žemva, O. Tamada, H. Yoshino, S. Matsubara, Dalton Transactions, 2004, 144.

(23) H. Yoshino, S. Matsubara, K. Oshima, K. Matsumoto, R. Hagiwara, Y. Ito, J. Fluorine Chem., 125, 455 (2004).

(24) H. Yoshino, K. Nomura, S. Matsubara, K. Oshima, K. Matsumoto, R. Hagiwara, Y. Ito, J. Fluorine Chem., 125, 1127 (2004).

(25) K. Momota, M. Morita, and Y. Matsuda, Electrochim. Acta., 38, 619 (1993).

(26) A. Noda, K. Hayamizu and M. Watanabe, J. Phys. Chem. B, 105, 4603 (2001).

(27) K. Momota, Youyuen Oyobi Kouon Kagaku, 45 (1), 42 (2002).

(28) R. Hagiwara, Y. Nakamori, K. Matsumoto, Y. Ito, J. Phys. Chem. B, submitted. 


\section{Figure captions}

Fig. 1 Structures of (a) EMIm ${ }^{+}$, (b) $\mathrm{EDMIm}^{+}$, (c) $(\mathrm{HF})_{2} \mathrm{~F}^{-}$and $(\mathrm{HF})_{3} \mathrm{~F}^{-}$.

Fig. 2 DSC curve of EDMIm(HF $)_{2.3} \mathrm{~F}$. Scan rate was $5 \mathrm{~K} \mathrm{~min}^{-1}$.

Fig. 3 Arrhenius plots of the viscosity and conductivity of $\operatorname{EDMIm}(\mathrm{HF})_{2.3} \mathrm{~F} . \circ$ : viscosity, $\square:$ conductivity.

Fig. 4 Comparison of electrochemical windows of (a) EDMIm(HF) $)_{2.3} \mathrm{~F}$ and (b)

EMIm(HF) ${ }_{2.3}$ F. W.E.: GC disk, C.E.: Pt plate, Scanning rate: $10 \mathrm{mV} \mathrm{s}^{-1}$. The potential is referenced to the potential of ferrocenium / ferrocene $\left(\mathrm{Fc}^{+} / \mathrm{Fc}\right)$ redox couple in each salt. 


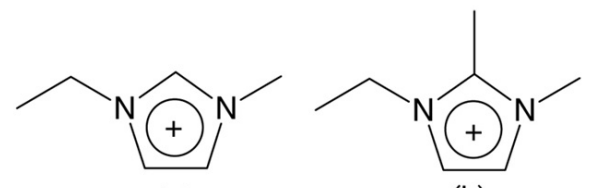

(a)

(b)

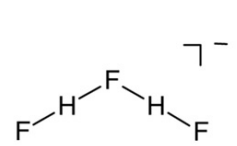

(c)

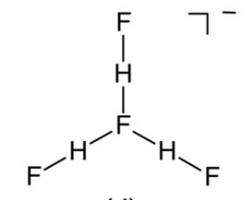

(d)

Fig. 1 Structures of (a) EMIm ${ }^{+}$, (b) EDMIm $^{+}$, (c) $(\mathrm{HF})_{2} \mathrm{~F}^{-}$ and $(\mathrm{HF})_{3} \mathrm{~F}^{-}$.

Fig. 1 (K. Matsumoto and R. Hagiwara) 


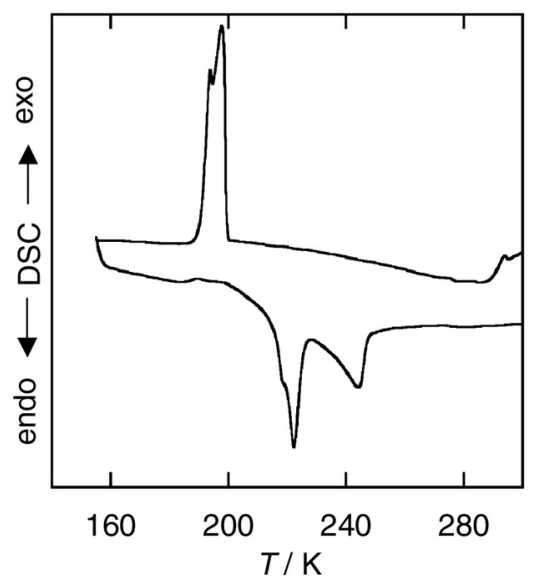

Fig. 2 DSC curve of EDMIm $(\mathrm{HF})_{2.3} \mathrm{~F}$. Scan rate was $5 \mathrm{~K}$ $\min ^{-1}$. 


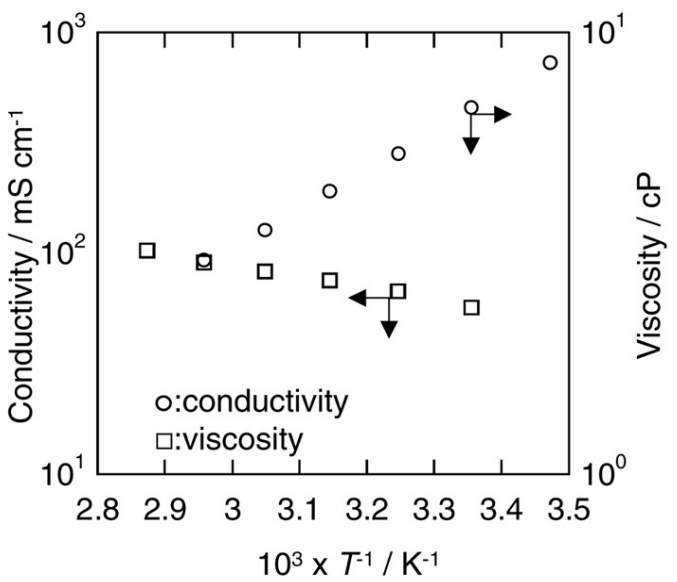

Fig. 3 Arrhenius plots of the viscosity and conductivity of $\operatorname{EDMIm}(\mathrm{HF})_{2.3} \mathrm{~F}$. ०: viscosity, $\square$ :conductivity. 


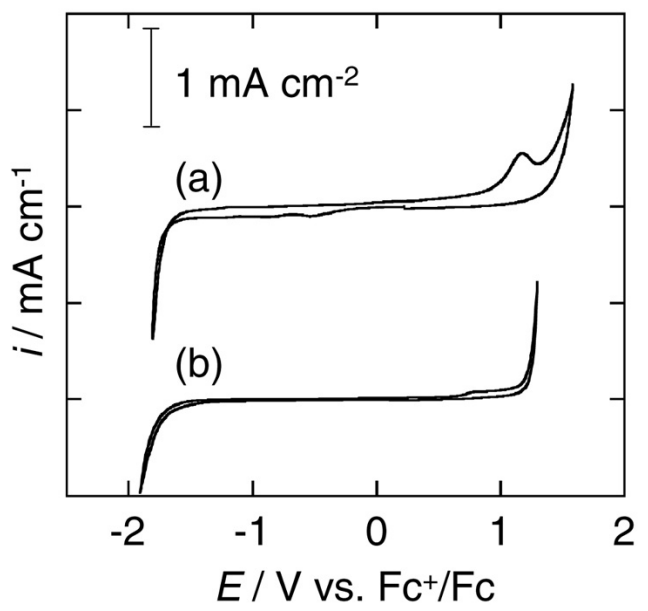

Fig. 4 Comparison of electrochemical windows of (a) $\operatorname{EDMIm}(\mathrm{HF})_{2.3} \mathrm{~F}$ and (b) $\operatorname{EMIm}(\mathrm{HF})_{2.3}$ F. W.E.: GC disk, C.E.: Pt plate, Scanning rate: $10 \mathrm{mV} \mathrm{s}^{-1}$. The potential is referenced to the potential of ferrocenium / ferrocene $\left(\mathrm{Fc}^{+} / \mathrm{Fc}\right)$ redox couple in each salt. 
Table 1 Comparison of physical properties of $\operatorname{EDMIm}(\mathrm{HF})_{2.3} \mathrm{~F}$ and $\mathrm{EMIm}(\mathrm{HF})_{2.3} \mathrm{~F}$ at $298 \mathrm{~K}$.

\begin{tabular}{cccccccc}
\hline \multicolumn{1}{c}{ Salts } & $\mathrm{M}$ & $T_{S}$ & $T_{L}$ & $T_{g}$ & $\rho$ & $\eta$ & $\sigma$ \\
& $\mathrm{W}$ & $/ \mathrm{K}$ & $/ \mathrm{K}$ & $/ \mathrm{K}$ & $/ \mathrm{g} \mathrm{cm}^{-3}$ & $/ \mathrm{cP}$ & $/ \mathrm{mS} \mathrm{cm}^{-1}$ \\
\hline EDMIm$(\mathrm{HF})_{2.3} \mathrm{~F}$ & 188 & 215 & 237 & - & 1.10 & 6.8 & 56.9 \\
EMIm $(\mathrm{HF})_{2.3} \mathrm{~F}^{18)}$ & 176 & 208 & 208 & 148 & 1.13 & 4.9 & 100 \\
\hline
\end{tabular}

MW: molecular weight, $T_{S}$ : solidus temperature, $T_{L}$ : liquidus temperature, $T_{g}$ : glass transition temperature, $\rho$ : density, $\eta$ : viscosity, $\sigma$ : conductivity. 